
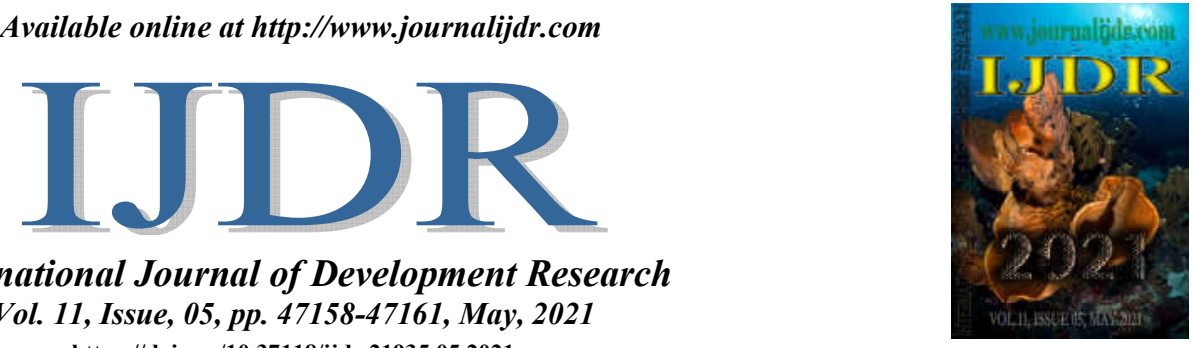

ISSN: $2230-9926$

International Journal of Development Research

Vol. 11, Issue, 05, pp. 47158-47161, May, 2021

https://doi.org/10.37118/ijdr.21935.05.2021

\title{
SQUAMOUS CELL CARCINOMA IN YOUNG NON-SMOKER PATIENT: CASE REPORT
}

\section{${ }^{1}$ Amanda de Almeida Lima Borba Lopes, ${ }^{1,2}$ Letícia CôgoMarques, ${ }^{1}$ Katryne da Costa, ${ }^{1}$ Rafaela Elvira Rozza-de Menezes, ${ }^{1}$ Karin Soares Cunha, ${ }^{1}$ Arley Silva Junior and ${ }^{* 1,3}$ Danielle Castex Conde}

1Postgraduate Program in Pathology, School of Medicine, Universidade Federal Fluminense (UFF), Niterói, RJ, Brazil; 2Dentistry Sector, Healthcare and Social Assistance Section of The Universidade Federal do Espírito Santo (UFES), Espírito Santo, ES, Brasil; ${ }^{3}$ Oral Maxillofacial Surgery and Traumatology Service and Anatomical Pathology Service, Military Police Central Hospital (Hospital Central da Polícia Militar), Rio de Janeiro State Military Police, Rio de Janeiro, RJ, Brazil

\section{ARTICLE INFO}

\section{Article History:}

Received $11^{\text {th }}$ February, 2021

Received in revised form

$16^{\text {th }}$ March, 2021

Accepted $23^{\text {rd }}$ April, 2021

Published online $30^{\text {th }}$ May, 2021

Key Words:

Squamous cell carcinoma, Oral cancer,

Oral Malignant neoplasia, Youth oral cancer,

Mouth cancer.

*Corresponding autho:

Danielle Castex Conde

\begin{abstract}
Squamous cell carcinoma (SCC) represents approximately $90 \%$ of all oral malignant neoplasms. Oral SCC is more common in white men between the sixth and seventh decades of life, alcoholics, and smokers, and affects mainly the lateral border of the tongue. When it affects young people, it occurs predominantly in non-smoker and non-alcoholic women and the commonsite isthe lateral border of the tongue. Its incidence in young individuals is increasing, and their mechanisms of development are still undefined. This paper aims to report a case of SCC in the lateral border of the tongue in a 25 -year-old black man.
\end{abstract}

Copyright (C) 2021, Amanda de Almeida Lima Borba Lopes et al. This is an open access article distributed under the Creative Commons Attribution License, which permits unrestricted use, distribution, and reproduction in any medium, provided the original work is properly cited.

Citation: Amanda de Almeida Lima Borba Lopes, Letícia CôgoMarques, 1Katryne da Costa, Rafaela Elvira Rozza-de Menezes, Karin Soares Cunha, Arley Silva Junior and Danielle Castex Conde. 2021. "Squamous cell carcinoma in young non-smoker patient: case report", International Journal of Development Research, 11, (05), 47158-47161.

\section{INTRODUCTION}

Squamous cell carcinoma (SCC) represents approximately $90 \%$ of all oral malignant neoplasms, and the majority of cases are preceded by potentially malignant disorders(EL-NAGGAR ET AL., 2017). Generally, oral SCC affects men between the sixth and seventh decades of life, alcoholics, and smokers(CHEN et al., 2020; DOS SANTOS COSTA et al., 2018; NASSER; ST JOHN, 2020; PICKERING et al., 2014), and mainlythe lateral border and ventral surface of the tongue, floor of the mouth, and soft palate(SANTOSSILVA et al., 2014). The occurrence of oral SCC in young white female patients with no history of smoking and alcohol use has increased in recent years(ADDURI et al., 2014; BARNABÉ et al., 2019; CAMPBELL et al., 2019; CHEN et al., 2020; LLEWELLYN et al., 2004; MAHMOOD et al., 2018; MAROUN et al., 2020; MIRANDA GALVIS et al., 2018; NASSER; ST JOHN, 2020; PICKERING et al., 2014; VAN MONSJOU et al., 2013).Nevertheless, this high incidence has not yet been explained by genetic alterations, habits, or other factors, unlikeoropharyngeal carcinomain young patients, which has been strongly related to human papillomavirus (HPV)(YOSEFOF et al., 2020).
Thus, studies on oral SCC in young people arevery important to elucidate the controversial aspects that involve the etiopathogenesis of the disease, contributing to an early diagnosis and reduction of high rates of morbidity and mortality. This paper aims to report a case of SCC on the lateral border of the tongue in a 25 -year-old nonsmoker black man.

\section{CASE REPORT}

A 25-year-old black male was referred to the Oral Diagnostic Clinic of Antônio Pedro University Hospital (HUAP) of Universidade Federal Fluminense (UFF) for evaluation of an asymptomatic oral lesion, with a two-year evolution. During the anamnesis, the patient denied smoking and reported social drinking, with a frequency of ingestion twice a month, since he was 17 years old. The patient had no family history of cancer, and his laboratory tests were negative for syphilis (Venereal Disease Research Laboratory - VDRL), hepatitis B (Hepatitis B surface antigen - HBsAg), hepatitis C (Anti-HCV), HPV (anti-p16), and human immunodeficiency virus (Anti-HIV). In the intraoral exam, a $2.5 \times 0.5 \mathrm{~cm}$ lesion on the left side of the tongue was identified, composed of a heterogeneous white plaque with thin 

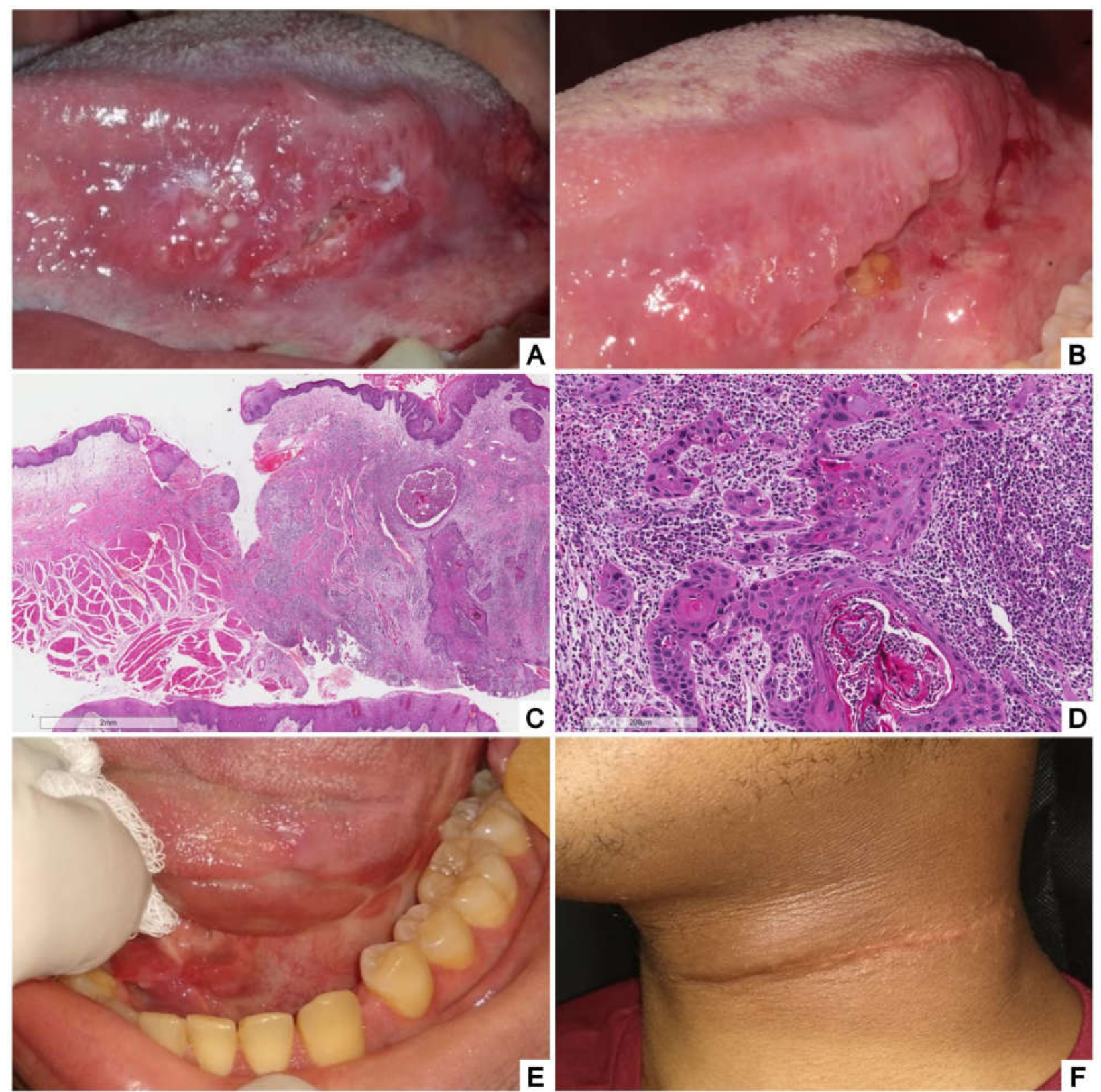

Figure 1. Clinical and histopathological aspects. White and non-homogenous plaque, with thin and thick areas with approximately 2.5 $x 0.5 \mathrm{~cm}$, exhibiting ulceration with indurated border on the left lateral border of the tongue (A). Clinical aspects after one week of the biopsy (B). Histopathology demonstrated mucosal tongue with ulceration and invasion of the connective tissue with epithelial nests depicting hyperchromatic nuclei and pleomorphic cells and nuclei, mitosis and atypical keratin pearls were seen, and a diagnosis of moderately differentiated squamous cell carcinoma was confirmed (C and D). Surgical scar on the left lateral border of the tongue (E). Surgical scar on the cervical area after lymph nodes removal (F).

and thick areas, as well as red areas and ulcer. The edges of the lesion were hard (Fig 1 A and B). Fixed and hard lymph nodes of sudden appearance were palpableonthe left side of the submandibular area. The clinical diagnostic hypothesis was SCC. An incisional biopsy was performed and the histopathological exam showed an ulcerated lesion, with invasionof the epithelium into the underlying connective tissue. The nests of epithelial cellsshowed keratinocyteswith hyperchromatic nuclei, cellular and nuclear pleomorphism, and numerous figures of mitosis, including atypical ones.Keratin pearls were also seen in the nests of epithelial cells. The diagnosis was moderately differentiated squamous cell carcinoma (Fig. $1 \mathrm{C}$ and D). The patient was referred to the National Cancer Institute (INCA) for treatment, where was submitted to surgical removal of the tumor with free surgical margins, as well as ganglionic emptying (pathological classification $\mathrm{pT} 3 \mathrm{pN} 2 \mathrm{a}$ and clinic III).Adjuvant radiotherapy and immunotherapy protocols were performed. Radiotherapy comprised 33 sessions, a dose of $60 \mathrm{GY}$ in 30 sessions, and reinforcement of a dose of $6 \mathrm{GY}$ in three applications.
Two cycles of immunotherapy with Atezolizumab(1200 mg)were conducted. Moreover, recovering from the surgery, the patient performed five speech therapy sessions, with no difficulties in the mobility of the tongue. The patient is being followed up for approximately two yearsat the Oral Diagnosis Clinic of the UFF HUAP, without signs and symptoms of recurrence.Clinically, there is a surgical scar on the tongue and left cervical region (Fig. $1 \mathrm{E}$ and F).

\section{DISCUSSION}

SCC in young people became a more serious problem after the 2000 s when epidemiological evidence showed a significant increase in cases(CHOI et al., 2019). The disease appears clinically and biologically distinct from that in older age(LLEWELLYN et al., 2004; MAROUN et al., 2020; VAN MONSJOU et al., 2013; YOSEFOF et al., 2020). Its etiology and pathogenesis are still not well understood and recently, attention has been given to the genetic 
factors research in developing of oral SCC in young people (MAHMOOD et al., 2018). It is known that genetic changesare determined by two main parameters: level of exposure to mutagenic factors and inherent ability to repair DNA damage efficiently (BODNER et al., 2014).Thebroad exposure to mutagens, on average, is higher in older patients, therefore, young patients seem to harbor a significantly lower number of mutations than older individuals (BODNER et al., 2014; MAROUN et al., 2020). Oral SCC among individuals with diseases or syndromes that predispose to cancer development is probably related to genetic instability(BODNER et al., 2014). People with genetic syndromes, such as Fanconi anemia, xerodermapigmentosus, congenital dyskeratosis, and the graft-versushost disease, are at increased risk for the development of SCC in the first two decades of life (BODNER et al., 2014). Immunohistochemical analyzes have shown that different molecular markers are involved in the development of oral SCC and the reported proteins are related to the cell cycle, local invasion, lymphatic growth, cell proliferation, and activation of cancer products(DOS SANTOS COSTA et al., 2018). The tumor suppressor gene TP53 is the most frequently mutated gene in human cancers and the $\mathrm{p} 53$ protein expression has been used as a marker for mutation in SCC(DOS SANTOS COSTA et al., 2018; PICKERING et al., 2014). Although tobacco and alcohol are known to increase the frequency of TP53 mutations in head and neck cancers(BRENNAN et al., 2007), a study by Pickering et al.(2014) of tongue cancer in nonsmoking patients over and under 45 years old observed a trend towards a higher rate of TP53 mutation among younger patients. However, this difference was not statistically significant(PICKERING et al., 2014).Other studies have identified a high proportion of $\mathrm{p} 53$ immunoexpression in younger patients (ADDURI et al., 2014; DE PAULA et al., 2009). In contrast, Choi et al.(2019)showed thatp53 expression was not statistically different when comparing the different age groups. Therefore there is a divergence in the literature regardingTP53 mutations in oral SCC in young people.

Regarding immunological responses, it has been reported that younger patients with oral SCC appear to have an attenuated immune response, which may be related to a higher frequency of immunogenic mutations in $A T M, B R C A 1, E 2 F 1$, and FHIT genes (KNOPF et al., 2015). Other studies compared the expression of other biomarkers between young and elderly and found a greater expression of p16(BARNABÉ et al., 2019), cyclin D1(KAMINAGAKURA et al., 2011), EGFR, VEGF-C3(DOS SANTOS COSTA et al., 2018), C-ErbB2(MIRANDA GALVIS et al., 2018), CYP1B1(KAMINAGAKURA et al., 2011), MMP-9(DOS SANTOS COSTA et al., 2018),SMAm(MIRANDA GALVIS et al., 2018), and podoplanin in young patients(DOS SANTOS COSTA et al., 2018).However, the different expression patterns deserve a better investigation to understand the role of these molecules in the development of oral SCC in young people. Tongue SCC can be considered a subtype of head and neck cancer, which affects mainly young patients, with a significant proportion not associated with classic risk factors(CAMPBELL et al., 2019).A study by Campbell et al.(2019) analyzed location distribution with regard age and found that the lower the age of the individual with oral SCC had a greater association with cases located on the tongue.The case described agrees with this study representing a young man, who was nonsmoker and with a low alcohol consumption habit, with a SCC located on the tongue. Commonly, the main risk factors for SCC development include smoking and alcohol consumption, which are strongly synergistic(VAN MONSJOU et al., 2013). However, despite the increasing use of smokeless tobacco products, such as chewing tobacco, in young people, no associations were observed between smoking (chewing tobacco, cigarettes, cigars, or pipes) and the development of tongue SCC under the age of 50(CAMPBELL et al., 2019).Moreover, studies suggest that exposure of young people to these carcinogenic agents does not last long enough to justify its malignant transformation(LLEWELLYN et al., 2004; NASSER; ST JOHN, 2020).However, the difficulty in determining the type, quantity, and frequency of the habit can be considered an important obstacle when interpreting the results(DOS SANTOS COSTA et al., 2018).
In the present case reported, the patient denied smoking and reported social drinking, with low frequency and dose. We believe that the short duration of exposure to the risk factor could not be sufficient for the malignancy development. In the last 15 years, it has been an increase in SCC incidence induced by HPV, especially subtypes 16 and 18, with a high frequency in young, non-smoking, and nonalcoholic individuals(SANTOS-SILVA et al., 2014). Although HPV infection has been well established as a factor in the development of oropharyngeal SCC, the possible involvement of HPV in the etiology of oral SCC is controversial(DOS SANTOS COSTA et al., 2018; NASSER; ST JOHN, 2020; SANTOS-SILVA et al., 2014). Regardless some authors consider that the increase in oral SCC in young people may be associated with HPV, most studies describe a low presence of this virus in oral SCC in young individuals (less than 11\%)(MELO et al., 2020).Interestingly, Kaminagakura et al.(2012) found a greater incidence of HPV16 in oral SCC in Brazilian young patients $(68.2 \%)$. This discrepancy in results may be related to the location of the tumor, geographic heterogeneity, and the different methods used for the detection of HPV(DOS SANTOS COSTA et al., 2018). In the present case, the investigation of HPV 16 was negative. The SCC treatment depends on the age, location, extension, and presence of metastasis, and consists mainly of surgical excision followed by radiotherapy(SANTOS-SILVA et al., 2014).In the present case, removal of the tumor with free surgical margins, lymphnode emptying, in addition to radiotherapy and immunotherapy was performed.

Immunotherapy is a biological therapy capable of inducing and/or regulating anti-tumor immune responses, representing a complementary approach to conventional treatments of cancer, with greater applicability in a minimal residual disease and reducing distant metastases after other therapeutic interventions(DAVIDSON et al., 2009). Emerging forms of immunotherapy in the treatment of SCC involve both the use of monoclonal antibodies (mAb), as well as various forms of vaccine strategies that activate and target cell immunity of the patient against the tumor(DAVIDSON et al., 2009). In the present case, immunotherapy with $\mathrm{mAb}$ (atezolizumab) was performed. Considering the prognosis, there is still no consensus about oral SCC in young patients(BODNER et al., 2014; DOS SANTOS COSTA et al., 2018). Studies suggest that oral SCC in young patients tends to be more aggressive, with less time for cancer development and regional metastases, quickly reaching advanced stages of the disease(ADDURI et al., 2014; DAVIDSON et al., 2009; DOS SANTOS COSTA et al., 2018).According to Saggi et al.,(2018) SCC in elderly patients has greater recurrence and shorter survival, probably due to the presence of common comorbidities in this age group, which can influence overall survival rates(MIRANDA GALVIS et al., 2018). So far, the patient is in clinical control and without signs of the disease. The lack of consensus in determining the age groups considered young and elderly was another obstacle for comparing the studies. The standardization of this criterion is fundamental for comparisons and to understand differences between the groups.

\section{CONCLUSION}

The etiology and pathogenesis of SCC in young patients are still uncertain and need further clarification and investigation.Although there are some differences aboutthe profile predominantly described in the literature, the present report contributes to understanding the SCC in young people. This occurrence in young patients with no smoking habit and low frequency of alcohol consumption suggests that genetic factors are involved in its development.

\section{REFERENCES}

Adduri R., Kotapalli V., Gupta N. A., et al. (2014) P53 nuclear stabilization is associated with FHIT loss and younger age of onset in squamous cell carcinoma of oral tongue. BMC Clin Pathol, v. 14, p. 37 
Barnabé L. É. G., Batista A. C., Mendonça E. F. de, Nonaka C. F. W., Alves P. M. et al. (2019) Cell cycle markers and apoptotic proteins in oral tongue squamous cell carcinoma in young and elderly patients. Braz Oral Res, v. 33, p. e103.

Bodner L., Manor E., Friger M. D., van der Waal I. et al. (2014) Oral squamous cell carcinoma in patients twenty years of age or younger--review and analysis of 186 reported cases. Oral Oncol, v. 50 , n. 2 , p. $84-89$

Brennan M., Migliorati C. A., Lockhart P. B. et al. (2007) Management of oral epithelial dysplasia: a review. Oral Surg Oral Med Oral Pathol Oral RadiolEndod, v. 103 Suppl, p. S19.e1-12.

Campbell B. R., Sanders C. B, Netterville J. L. et al. (2019)Early onset oral tongue squamous cell carcinoma: Associated factors and patient outcomes. Head Neck, v. 41, n. 6, p. 1952-1960.

Chen S., Lin Z., Chen J. et al. (2020) Older age is a risk factor associated with poor prognosis of patients with squamous cell carcinoma of the oral cavity. EurArchOtorhinolaryngol, v. 277, n. 9 , p. 2573-2580.

Choi G., Song J. S., Choi S. H. et al. (2019) Comparison of Squamous Cell Carcinoma of the Tongue between Young and Old Patients. J PatholTransl Med, v. 53, n. 6, p. 369-377, nov. 2019.

Davidson H. C., Leibowitz M. S., Lopez-Albaitero A., Ferris R. L. et al.(2009) Immunotherapy for head and neck cancer. Oral Oncology, v. 45, n. 9, p. 747-751.

De Paula A. M. B., Souza L. R., Farias L. C. et al.(2009) Analysis of 724 cases of primary head and neck squamous cell carcinoma (HNSCC) with a focus on young patients and p53 immunolocalization. Oral Oncology, v. 45, n. 9, p. 777-782.

Dos Santos Costa S. F., Brennan P. A., Gomez R. S. et al.(2018) Molecular basis of oral squamous cell carcinoma in young patients: Is it any different from older patients? J Oral Pathol Med, v. 47, n. 6, p. 541-546.

El-Naggar et al. (2017)Who Classification Of Head And Neck Tumours $4 \mathrm{Ed}$.

Kaminagakura E., Werneck da Cunha I., Soares F. A., Nishimoto I. N., Kowalski L. P.et al. (2011) CCND1 amplification and protein overexpression in oral squamous cell carcinoma of young patients. Head Neck, v. 33, n. 10, p. 1413-1419.

Kaminagakura E., Villa L. L., Andreoli M. A. et al. (2012) High-risk human papillomavirus in oral squamous cell carcinoma of young patients. Int J Cancer, v. 130, n. 8, p. 1726-1732.

Knopf A., Lempart J., Bas M., Slotta-Huspenina J., Mansour N., Fritsche M. K. (2015) Oncogenes and tumor suppressor genes in squamous cell carcinoma of the tongue in young patients. Oncotarget, v. 6, n. 5, p. 3443-3451.
Llewellyn CD, Linklater K, Bell J, Johnson NW, Warnakulasuriya S. (2004)An analysis of risk factors for oral cancer in young people: a case-control study. Oral Oncol, v. 40, n. 3, p. 304-313.

Mahmood N., Hanif M., Ahmed A., Jamal Q., Saqib N., Khan A. (2018) Impact of age at diagnosis on clinicopathological outcomes of oral squamous cell carcinoma patients. Pak $J$ MedSci, v. 34, n. 3, p. 595-599, jun..

Maroun C. A., Zhu G., Fakhry C. et al. (2020) An Immunogenomic Investigation of Oral Cavity Squamous Cell Carcinoma in Patients Aged 45 Years and Younger. Laryngoscope, 16.

Melo B. A. de C., Vilar L. G., Oliveira N. R. de et al.(2020) Human papillomavirus infection and oral squamous cell carcinoma - a systematic review. Brazilian Journal of Otorhinolaryngology, 29.

Miranda Galvis M., Santos-Silva A. R., Freitas Jardim J. et al.(2018) Different patterns of expression of cell cycle control and local invasion-related proteins in oral squamous cell carcinoma affecting young patients. J Oral Pathol Med, v. 47, n. 1, p. 32 39.

Nasser H., St John M. A. (2020)The promise of immunotherapy in the treatment of young adults with oral tongue cancer. Laryngoscope InvestigOtolaryngol, v. 5, n. 2, p. 235-242.

Pickering C. R., Zhang J., Neskey D. M. et al. (2014) Squamous cell carcinoma of the oral tongue in young non-smokers is genomically similar to tumors in older smokers. Clin Cancer Res, v. 20, n. 14, p. 3842-3848.

Saggi S., Badran K. W., Han A. Y., Kuan E. C., St John M. A. (2018)Clinicopathologic Characteristics and Survival Outcomes in Floor of Mouth Squamous Cell Carcinoma: A PopulationBased Study. Otolaryngol Head Neck Surg, v. 159, n. 1, p. 5158.

Santos-Silva A. R., Carvalho Andrade M. A., Jorge J., Almeida O. P., Vargas P. A., Lopes M. A. (2014) Tongue squamous cell carcinoma in young nonsmoking and nondrinking patients: 3 clinical cases of orthodontic interest. $\mathrm{Am} J$ OrthodDentofacialOrthop, v. 145, n. 1, p. 103-107.

Van Monsjou H. S., Wreesmann V. B., van den Brekel M. W. M., Balm A. J. M. (2013) Head and neck squamous cell carcinoma in young patients. Oral Oncol, v. 49, n. 12, p. 1097-1102.

Yosefof E., Hilly O., Stern S., Bachar G., Shpitzer T., Mizrachi A. (2020) Squamous cell carcinoma of the oral tongue: Distinct epidemiological profile disease. Head Neck, v. 42, n. 9, p. 2316 2320 . 